\title{
KIJING TAIWAN (Anodonta woodiana) SEBAGAI SUMBER KALSIUM TINGGI DALAM UPAYA MENCEGAH OSTEOPOROSIS
}

\author{
Sata Yoshida Srie Rahayu \\ Program Studi Biologi FMIPA Universitas Pakuan \\ Email : sata_rahayu@unpak.ac.id
}

\begin{abstract}
ABSTRAK
Kalsium merupakan mineral yang sangat dibutuhkan dalam tubuh manusia. Apabila kekurangan kalsium dapat menyebabkan riketsia pada anak, osteomalasia (tulang lunak) dan osteoporosis (tulang keropos) pada orang dewasa. Untuk mencegah hal tersebut maka dibutuhkan asupan kalsium yang cukup. Kurang sadarnya masyarakat akan pentingnya kalsium bagi tubuh mengakibatkan dua dari lima orang Indonesia terkena osteoporosis. Masyarakat Indonesia umumnya mengetahui sumber kalsium bagi tubuh manusia adalah susu serta produk olahannya. Kandungan kalsium pada susu sapi sebesar $143 \mathrm{mg}$ padahal terdapat sumber kalsium lain yang berpotensi yaitu memiliki kandungan kalsium lebih besar daripada susu yaitu kerang. Tujuan penelitian adalah untuk mengkaji komposisi kimia pada Kijing Taiwan dan merumuskan metode sosialisasi Kijing Taiwan sebagai sumber kalsium dalam upaya pencegahan osteoporosis. Manfaat penelitian adalah untuk memperkenalkan Kijing Taiwan sebagai menu makanan keluarga. Penentuan komposisi kimia proksimat, yang meliputi analisis kadar air, analisis kadar abu, analisis kadar protein, analisis kadar lemak dan analisis kadar karbohidrat dan kadar mineral $\mathrm{Ca}, \mathrm{Cu}, \mathrm{Fe}$ dan $\mathrm{Zn}$. Dalam penelitian ini kita dapat mengetahui kandungan kalsium pada Kijing Taiwan, yaitu 366 mg kalsium serta mengetahui berapa gram Kijing Taiwan yang harus dikonsumsi untuk memenuhi asupan kalsium per hari per orangnya, yaitu sebanyak 273 gr. Diharapkan dari lingkup yang kecil ini dapat mengurangi kasus osteoporosis di Indonesia.
\end{abstract}

Kata kunci $\quad$ : Kijing, Anodonta woodiana, sumber kalsium, osteoporosis

\section{PENDAHULUAN}

Kalsium merupakan mineral yang sangat dibutuhkan dalam tubuh manusia. Kalsium berperan penting dalam proses metabolisme tubuh, penghantar isyarat saraf, mengatur denyut jantung, pertumbuhan otot dan lain-lain. Kebutuhan kalsium pada manusia berbeda-beda tergantung tingkat usianya. Untuk memenuhi kebutuhan kalsium tersebut manusia harus mengkonsumsi makanan yang mengandung kalsium. Kekurangan kalsium pada tubuh manusia dalam jangka panjang akan mengakibatkan pengeroposan dan pengapuran pada tulang, kerusakan pada gigi, dan lain-lain (Deearyana 2006).

Masyarakat umumnya mengetahui bahwa sumber kalsium utama berasal dari susu. Kandungan kalsium pada susu sapi per 100\% Berat Dapat Dimakan (BDD) sebesar $143 \mathrm{mg}$. Padahal ada sumber kalsium lain yang berpotensi yaitu memiliki kandungan kalsium lebih besar daripada susu yaitu kerang (Nasoetion et al. 2009).

Indonesia sebagai negara kepulauan mempunyai perikanan laut yang cukup besar. Potensi sumber daya ikan di laut Indonesia diperkirakan mencapai 6,7 juta ton per tahun. Salah satu potensi perikanan laut tersebut adalah kerang. Data Dirjen Perikanan menunjukkan adanya kenaikan produksi kerang sebesar $11,73 \%$ selama tahun 1990-1993 (Direktorat Jenderal Perikanan, 1995). Melihat potensi sumber daya kerang yang melimpah di perairan Indonesia dan kandungan kalsiumnya yang tinggi maka kerang sangat bermanfaat 
untuk dijadikan sebagai sumber kalsium lain selain susu.

Saat ini banyak orang yang terkena osteoporosis. Puslitbang Gizi Depkes bekerja sama dengan Fonterra Brands Indonesia mempublikasikan bahwa 2 dari 5 orang Indonesia memiliki risiko mengalami osteoporosis. Hal ini disebabkan kurangnya kesadaran masyarakat dalam memenuhi kebutuhan kalsiumnya secara optimal. Misalnya dalam mengkonsumsi susu, masyarakat tidak mengkonsumsinya sesuai dengan kebutuhan kalsiumnya yaitu sebanyak 3 gelas per hari. Oleh karena itu diperlukan sosialisasi mengenai pentingnya memenuhi kebutuhan kalsium dengan memberikan alternatif menu makanan olahan berbahan dasar kerang (Departemen Kesehatan RI, 2009).

Tubuh manusia memerlukan mineral kalsium yang cukup bagi tubuh. Masyarakat umumnya memenuhi kebutuhan kalsiumnya hanya dengan mengkonsumsi susu. Banyak masyarakat yang belum memahami bahwa ada bahan makanan yang mengandung mineral kalsium paling tinggi yaitu kerang. Dalam penelitian ini akan dilakukan penentuan komposisi kimia proksimat kerang sebagai sumber kalsium.

Dokter dan ahli gizi pada umumnya menyarankan pasiennya yang menderita osteoporosis untuk mengkonsumsi lebih banyak susu sapi karena mengandung kalsium tinggi. Kedengarannya cukup masuk diakal, tetapi tidak akan berhasil. Orang Amerika dan Eropa Utara mengonsumsi $800 \mathrm{mg}$ - $1200 \mathrm{mg}$ kalsium sehari, tapi tetap saja mereka lebih menderita osteoporosis daripada orang Asia dan Afrika yang mengonsumsi 300 mg - 500 mg kalsium per hari.

Penyebab utama osteoporosis adalah terlalu banyak mengonsumsi acidic yang berasal dari daging, gula dan bahanbahan yang mengandung kimia. Untuk menetralisir aciditas tersebut, tubuh mengambil kalsium (alkalin) dari tulang. Sehingga masalah osteoporosis bukanlah bahwa seseorang itu tidak cukup memakan kalsium. Kebutuhan hidup yang semakin meningkat menyebabkan pengurangan alokasi dana terhadap makanan tambahan seperti susu. Kasus osteoporosis yang telah ramai dipergunjingkan merupakan efek dari kurangnya asupan kalsium sementara sumber kalsium yang saat ini dikenal masyarakat adalah susu. Berdasarkan data dari Puslitbang Gizi Depkes, dua dari lima orang Indonesia berpeluang untuk terkena osteoporosis. Hal ini mengindikasikan kurangnya asupan kalsium pada masingmasing individu (Departemen Kesehatan RI 2009).

Pemenuhan kebutuhan kalsium setiap harinya menjadi pilihan sulit bagi setiap ibu rumah tangga selaku pemegang kendali dalam keuangan rumah tangga dan pengatur menu makanan untuk keluarganya. Kesulitan pemenuhan kebutuhan kalsium dikarenakan harga susu yang beredar di pasaran terus meningkat tidak sebanding dengan kenaikan pengahasilan yang didapatkan. Oleh karena itu dibutuhkan suatu alternatif sumber kalsium baru yang dapat mensubtitusi susu dengan kandungan kalsium yang tinggi dengan harga yang terjangkau. Sumber kalsium yang dapat dikembangkan adalah kerang.

Tujuan dari penelitian ini adalah untuk mengkaji komposisi kimia proksimat, yang meliputi analisis kadar air, analisis kadar abu, analisis kadar protein, analisis kadar lemak dan analisis kadar karbohidrat dan mineral $\mathrm{Cu}, \mathrm{Fe}$ dan $\mathrm{Zn}$ pada daging kerang air tawar yaitu Kijing Taiwan serta merumuskan metode sosialisasinya sebagai sumber kalsium dalam upaya pencegahan ospteoporosis.

Penelitian ini bermanfaat sebagai peluang untuk memperkenalkan Kijing Taiwan kepada masyarakat khususnya ibu rumah tangga dalam pengolahan menu makanan olahan yang berbahan dasar kerang.

\section{Kalsium dan Osteoporosis}


Asupan kalsium yang memadai adalah penting untuk mencapai massa tulang yang optimal (optimal peak bone mass/PBM) dan mengatur laju kehilangan kalsium dari tulang dengan bertambahnya usia. Secara umum, fungsi kalsium adalah membangun tulang dan gigi, mengatur proses-proses tubuh dalam darah dan jaringan, dan membantu proses penggumpalan darah. (Nasoetion et al. 2009)

Tabel 1. Angka Kecukupan Gizi Kalsium Rata-rata yang Dianjurkan (per orang per hari) 2004.

Anak

\begin{tabular}{cc}
\hline Umur & Kalsium $(\mathrm{mg})$ \\
\hline $0-6$ bln & 200 \\
$7-12$ bln & 400 \\
$1-3$ thn & 500 \\
$4-6$ thn & 500 \\
7-9 thn & 600 \\
\hline
\end{tabular}

Pria dan Wanita

\begin{tabular}{cc}
\hline Umur & Kalsium $(\mathrm{mg})$ \\
\hline $10-12$ thn & 1000 \\
$13-15$ thn & 1000 \\
$16-18$ thn & 1000 \\
$19-29$ thn & 800 \\
$30-49$ thn & 800 \\
$50-64$ thn & 800 \\
65 thn + & 800 \\
\hline
\end{tabular}

Sumber : Nasoetion et al. 2009.

Dari tabel di atas dapat diketahui bahwa kebutuhan kalsium setiap orang berbeda tergantung dari usia. Pada masa kanak-kanak asupan kalsium yang dibutuhkan per harinya masih sedikit sedangkan pada umur 10-18 tahun asupan kalsium sangat dibutuhkan untuk pertumbuhan. Ketika memasuki usia produktif (19-49 tahun) hingga non produktif, asupan kalsium yang dibutuhkan sedikit berkurang namun harus tetap dipenuhi untuk menunjang aktifitas mereka dan menjaga kekuatan tulang mereka.

Kekurangan kalsium dapat menyebabkan riketsia pada anak, osteomalasia atau tulang lunak dan osteoporosis atau tulang keropos pada orang dewasa. Osteoporosis adalah gangguan yang menyebabkan penurunan secara bertahap jumlah dan kekuatan jaringan tulang. Penurunan tersebut disebabkan oleh terjadinya demineralisasi tulang, yaitu tubuh yang kekurangan kalsium akan mengambilnya dari tulang dan gigi. (Departemen Kesehatan RI 2007). International Osteoporosis Foundation (IOF) memperkirakan, 150 juta orang di seluruh dunia terdeteksi menderita osteoporosis dan berisiko mengalami patah tulang yang dapat melumpuhkan dan menurunkan kualitas hidup.

Kebutuhan tubuh akan kalsium bisa dipenuhi dengan mengkonsumsi makanan sumber kalsium. Bahan makanan yang mengandung sumber kalsium paling tinggi terdapat pada kerang (Koral AUP/STP Papua 2008).

\section{Kijing Taiwan (Anodonta woodiana)}

Di Indonesia, Anodonta woodiana merupakan alien spesies dari Taiwan sejak tahun 1971 dan sudah lama dikenal penduduk serta memiliki potensi ekonomi dan ekologi yang besar. A. woodiana merupakan salah satu sumber protein hewani, dengan kandungan nutrisi yang baik. Bagian tubuh kijing ini juga digunakan sebagai bahan pakan ternak dan obat penyakit kuning. Cangkangnya sebagai bahan industri kancing dan penghasil mutiara air tawar (Rahayu, 2011).

Pemanfaatan A. woodiana yang dilakukan selama ini hanya sebagai pakan ternak, industri kancing, dan biofilter, sementara kemampuan biologisnya untuk memproduksi mutiara belum banyak diketahui. Jika melihat lebih detil anatomi dan proses biokimia jaringan tubuhnya, ternyata Anodonta sp. mampu mendeposit crystaline calcium carbonat $\left(\mathrm{CaCO}_{3}\right)$ dalam bentuk kristal aragonit yang dikenal sebagai nacre, dan komponen pembentuk lapisan prismatik yaitu kristal hexagonal 
calsite conchiolin $\left(\mathrm{C}_{32} \mathrm{H}_{48} \mathrm{~N}_{2} \mathrm{O}_{11}\right)$ pada lapisan cangkang bagian dalam.

Di bawah ini diperlihatkan daftar komposisi bahan makanan kerang (Tabel 2). Tabel Berdasarkan data di atas dapat dilihat kandungan protein, lemak, karbohidrat pada kerang dalam bentuk kerang segar dan kerang rebus.
Tabel di bawah ini menyajikan daftar komposisi bahan makanan yang terkandung pada susu serta produk olahannya. Berdasarkan data di atas dapat dilihat kandungan protein, lemak, karbohidrat pada komposisi bahan makanan susu serta produk olahannya.

Tabel 2. Daftar Komposisi Bahan Makanan Kerang

\begin{tabular}{|c|c|c|c|c|c|c|}
\hline No & Gol & Nama Pangan & BDD & Protein & Lemak & Karbohidrat \\
\hline & & & $\%$ & $\%$ & $\%$ & $\%$ \\
\hline 1 & 5 & $\begin{array}{c}\text { Kijing Taiwan } \\
\text { segar }\end{array}$ & 100 & 23,23 & 7,01 & 3,55 \\
\hline 2 & 5 & $\begin{array}{c}\text { Kijing Taiwan } \\
\text { rebus }\end{array}$ & 100 & 19,48 & 2,50 & 3,75 \\
\hline
\end{tabular}

Tabel 3. Daftar Komposisi Bahan Makanan Susu dan Olahannya

\begin{tabular}{cclccccc}
\hline No & Gol & Nama Pangan & BDD & Energi & Protein & Lemak & KH \\
\hline & & & $\%$ & Kal & $\mathrm{G}$ & $\mathrm{g}$ & $\mathrm{g}$ \\
1 & 8 & Es krim & 100 & 207 & 4 & 12.5 & 20.6 \\
2 & 8 & Keju & 100 & 326 & 22.8 & 20.3 & 13.1 \\
3 & 8 & Kelapa susu & 100 & 204 & 2.6 & 20 & 4 \\
4 & 8 & Mentega & 100 & 725 & 0.5 & 81.6 & 1.4 \\
5 & 8 & Susu Ibu (ASI) & 100 & 65 & 1.1 & 3.5 & 7.7 \\
6 & 8 & Susu Kambing & 100 & 64 & 4.3 & 2.3 & 6.6 \\
7 & 8 & Susu Kental Manis & 100 & 336 & 8.2 & 10 & 55 \\
8 & 8 & Susu Kental Tak Manis & 100 & 138 & 7 & 7.9 & 9.9 \\
9 & 8 & Susu Kerbau & 100 & 160 & 6.3 & 12 & 7.1 \\
10 & 8 & Susu Sapi & 100 & 61 & 3.2 & 3.5 & 4.3 \\
11 & 8 & Susu Skim(tak berlemak) & 100 & 36 & 3.5 & 0.1 & 5.1 \\
12 & 8 & Tepung Susu & 100 & 509 & 24.6 & 30 & 36.2 \\
13 & 8 & Tepung Susu Asam, untuk & 100 & 418 & 19 & 9 & 65.5 \\
14 & 8 & bayi & 100 & 362 & 35.6 & 1 & 52 \\
15 & 8 & Yopung Susu Skim & 100 & 52 & 3.3 & 2.5 & 4 \\
\hline
\end{tabular}

Sumber : Daftar Komposisi Bahan Makanan (Dept. Gizi Masy. FEMA IPB 2009)

\section{BAHAN DAN METODE}

Penelitian ini dilaksanakan di laboratorium nutrisi BBPBAT Sukabumi dari bulan April hingga Agustus 2010.

\section{Bahan dan Alat}

Alat-alat yang digunakan pada tahap persiapan sampel adalah pisau, talenan, timbangan digital dan kertas label. Alat untuk analisis proksimat dan AAS yang dilengkapi dengan $\mathrm{AC}$ lampu $\mathrm{Ca}, \mathrm{Cu}$, $\mathrm{Fe}, \mathrm{Zn}$ dan gas $\mathrm{O} 2$ dan $\mathrm{NO}_{2}$ yang digunakan untuk analisis mineral.

Bahan yang digunakan sebagai sampel adalah Kijing Taiwan A. woodiana 
yang berasal dari Kolam Percobaan BDP, Kampus Darmaga IPB.

\section{Analisis Proksimat}

Penentuan komposisi kimia (proksimat) dan AAS (Atomic Absorption Spectrophotometry) untuk analisis mineral $\mathrm{Cu}, \mathrm{Fe}$, dan $\mathrm{Zn}$, yang meliputi:

\section{a. Analisis kadar air (AOAC 1995)}

Perhitungan kadar air dilakukan dengan menggunakan rumus:

Kadar air $=\underline{\mathrm{B} 1-\mathrm{B} 2} \times 100 \%$

\section{$\mathrm{B}$}

Keterangan :

$\mathrm{B}=$ Berat sampel $(\mathrm{g})$

B1 = Berat (sampel+cawan) sebelum dikeringkan

B2 = Berat (sampel+cawan) setelah dikeringkan

\section{b. Analisis kadar abu (AOAC 1995)}

Perhitungan kadar abu dilakukan dengan menggunakan rumus:

Kadar abu $=$ Berat abu (g) $\times 100 \%$

$$
\text { Berat sampel (g) }
$$

\section{c. Analisis kadar protein (AOAC 1995)}

Perhitungan kadar protein

dilakukan dengan menggunakan rumus:

$\% \mathrm{~N}=\frac{(\mathrm{ml} \text { sampel }-\mathrm{ml} \mathrm{HCl} \text { blanko }) \times \mathrm{N} \mathrm{HCl} \times 14,007}{\text { Berat sampel }(\mathrm{g})} \times 100 \%$

$\%$ Protein $=\% \mathrm{~N} \times 6,25$

\section{d. Analisis kadar lemak (AOAC 1995)}

Perhitungan kadar lemak dilakukan dengan menggunakan rumus:

$$
\text { Kadar lemak }=\frac{\text { Berat lemak }(\mathrm{g})}{\text { Berat sampel }(\mathrm{g})} \times 100 \%
$$

\section{e. Perhitungan kadar karbohidrat (AOAC 1995)}

Perhitungan kadar karbohidrat dilakukan dengan menggunakan rumus:

Kadar karbohidrat $=100 \%-$ K.lemak $-\mathrm{K}$. protein - K. air - K.abu

\section{Metode Sosialisasi}

Metode penyampaian informasi mengenai pentingnya kalsium bagi tubuh serta pengenalan Kijing Taiwan sebagai sumber kalsium adalah dengan penyuluhan.

Metode penyuluhan ini meliputi beberapa tahapan, yaitu:

1. Memberikan pemaparan tentang pentingnya pemenuhan kalsium bagi tubuh. Dalam tahap ini juga diinformasikan data analisis mengenai perbandingan kalsium pada susu serta produk olahannya dan kerang. Hal ini dapat dilakukan pada saat acara arisan RW.

2. Mengajak para ibu rumah tangga untuk memanfaatkan Kijing Taiwan yang berguna sebagai asupan kalsium anggota keluarga dalam bentuk menu makanan olahan kerang.

3. Memberikan motivasi kepada para ibu rumah tangga untuk melakukan inovasi dalam pengolahan Kijing Taiwan menjadi menu makanan yang menarik dan disukai oleh anggota keluarga. Motivasi yang diberikan berupa kegiatan lomba cipta menu masakan olahan berbahan dasar kerang. Setiap resep menu masakan yang dibuat akan dikumpulkan menjadi satu buku yang kemudian dapat dijadikan panduan dalam memilih variasi menu masakan berbahan dasar Kijing Taiwan bagi para ibu rumah tangga di lingkungan tersebut

\section{HASIL DAN PEMBAHASAN \\ Komposisi Kimia Bahan Makanan Kijing Taiwan dan Susu \\ Berdasarkan hasil penelitian} diperlihatkan daftar komposisi bahan makanan Kijing Taiwan dan susu serta produk olahannya sebagai perbandingan kandungan kalsium yang dikandung oleh kedua jenis sumber kalsium (Tabel 4 dan tabel 5). 
Tabel 4. Daftar Komposisi Kimia Bahan Makanan Kerang

\begin{tabular}{lllllll}
\hline No & Gol & Nama Pangan & BDD (\%) & Protein (\%) & Lemak (\%) & Karbohidrat (\%) \\
\hline 1 & 5 & Kijing Taiwan segar & 100 & 7,37 & 0,78 & 3,3 \\
& & & Air (\%) & Abu (\%) & & \\
2 & 5 & Kijing Taiwan segar & 81,82 & 2 & & \\
& & & BDD (\%) & Kalsium ppm & Fe (\%) & Zn (\%) \\
3 & 5 & Kijing Taiwan segar & 100 & $\mathbf{3 6 6}$ & 0,10 & 0,05 \\
4 & 5 & Kijing Taiwan rebus & 100 & $\mathbf{3 5 9 , 2 7}$ & 14,25 & 3,53 \\
\hline
\end{tabular}

Tabel 5. Daftar Komposisi Kalsium dan Vitamin Bahan Makanan Susu dan Olahannya

\begin{tabular}{lllccccc}
\hline No & Gol & Nama Pangan & $\begin{array}{c}\text { Kalsium } \\
\text { mg }\end{array}$ & $\begin{array}{c}\text { BDD } \\
\text { \% }\end{array}$ & $\begin{array}{c}\text { Vit. A } \\
\text { mg }\end{array}$ & $\begin{array}{c}\text { Vit. B } \\
\text { RE }\end{array}$ & $\begin{array}{c}\text { Vit. C } \\
\text { mg }\end{array}$ \\
\hline 1 & 8 & Es krim & $\mathbf{1 2 3}$ & 100 & 178 & 0.04 & 1 \\
2 & 8 & Keju & $\mathbf{7 7 7}$ & 100 & 257 & 0.01 & 1 \\
3 & 8 & Kelapa susu & $\mathbf{9 7}$ & 100 & 285 & 0.03 & 1 \\
4 & 8 & Mentega & $\mathbf{1 5}$ & 100 & 1131 & 0 & 0 \\
5 & 8 & Susu Ibu (ASI) & $\mathbf{3 5 . 3}$ & 100 & 70 & 0.16 & 2.7 \\
6 & 8 & Susu Kambing & $\mathbf{9 8}$ & 100 & 43 & 0.06 & 1 \\
7 & 8 & Susu Kental Manis & $\mathbf{2 7 5}$ & 100 & 175 & 0.05 & 1 \\
8 & 8 & Susu Kental Tak Manis & $\mathbf{2 4 3}$ & 100 & 137 & 0.05 & 1 \\
9 & 8 & Susu Kerbau & $\mathbf{2 1 6}$ & 100 & 27 & 0.04 & 1 \\
$\mathbf{1 0}$ & $\mathbf{8}$ & Susu Sapi & $\mathbf{1 4 3}$ & $\mathbf{1 0 0}$ & $\mathbf{4 5}$ & $\mathbf{0 . 0 3}$ & $\mathbf{1}$ \\
11 & 8 & Susu Skim(tak berlemak) & $\mathbf{1 2 3}$ & 100 & 0 & 0.04 & 1 \\
12 & 8 & Tepung Susu & $\mathbf{9 0 4}$ & 100 & 538 & 0.29 & 6 \\
13 & 8 & Tepung Susu Asam, untuk bayi & $\mathbf{8 0 0}$ & 100 & 343 & 1 & 30 \\
14 & 8 & Tepung Susu Skim & $\mathbf{1 3 0 0}$ & 100 & 0 & 0.35 & 7 \\
15 & 8 & Yoghurt & $\mathbf{1 2 0}$ & 100 & 25 & 0.04 & 0 \\
\hline Sum & & Daftar Komposisi Bahan Makanan (Dept. Gizi Masy. & & \\
\hline
\end{tabular}

Sumber : Daftar Komposisi Bahan Makanan (Dept. Gizi Masy. FEMA IPB 2009)

Tabel diatas menyajikan daftar komposisi bahan makanan yang terkandung pada kerang. Berdasarkan data di atas dapat dilihat kandungan kalsium pada Kijing Taiwan dalam berbagai pengolahannya. Kandungan kalsium yang paling tinggi dalam $100 \%$ BDD terdapat pada Kijing Taiwan rebus sebesar $366 \mathrm{mg}$. Sedangkan kandungan kalsium yang paling rendah terdapat pada Kijing Taiwan segar sebesar 359,27 mg. Namun, data yang dipakai dalam perhitungan zat gizi kalsium yaitu Kijing Taiwan segar. Pemilihan Kijing Taiwan ini karena jenis dari Kijing Taiwan segar yang belum diolah untuk dibandingkan dengan susu sapi.

\begin{abstract}
Tabel diatas menyajikan daftar komposisi bahan makanan yang terkandung pada susu serta produk olahannya. Berdasarkan data di atas dapat dilihat kandungan kalsium pada susu dan produk olahannya. Kandungan kalsium yang paling tinggi dalam 100\% BDD terdapat pada tepung susu skim sebesar 1300 mg. Sedangkan kandungan kalsium yang paling rendah terdapat pada mentega sebesar $15 \mathrm{mg}$. Namun, data yang dipakai dalam perhitungan zat gizi kalsium yaitu susu sapi sebesar $143 \mathrm{mg}$. Pemilihan susu sapi ini karena jenis susu inilah yang sering dikonsumsi oleh masyarakat.
\end{abstract}


Analisis Perbandingan Kandungan Gizi Kalsium dari Kijing Taiwan dan Susu

Kandungan kalsium dalam $100 \mathrm{~g}$ bahan makanan menurut DKBM (Daftar Komposisi Bahan Makanan), 100 g susu sapi mengandung $143 \mathrm{mg}$ kalsium, $100 \mathrm{~g}$ Kijing Taiwan mengandung $366 \mathrm{mg}$ kalsium.

Secara umum, untuk menghitung jumlah zat gizi bahan pangan dirumuskan sebagai berikut :

$$
\begin{aligned}
& K g i j=\frac{B j}{100} \times G i j \times \frac{B D D}{100} \\
& B j=\frac{K g i j}{G i j} \times \frac{100}{B D D} \times 100
\end{aligned}
$$

Keterangan :

Kgij = kandungan zat gizi i dari bahan makanan $\mathrm{j}$ dengan berat $\mathrm{B}$ gram

$\mathrm{Bj} \quad=$ berat makanan $\mathrm{j}(\mathrm{g})$

Gij = Kandungan zat gizi i dalam $100 \mathrm{~g}$ BDD bahan makanan $\mathrm{j}$

$\mathrm{BDD}=$ persen bahan makanan $\mathrm{j}$ yang dapat dimakan (\% BDD)

Berikut adalah salah satu contoh perhitungan perbandingan antara susu sapi dan Kijing Taiwan untuk memenuhi kebutuhan kalsium pada masa pertumbuhan (10-18 tahun) yaitu sebesar $1000 \mathrm{mg}$.

1. Berapa gram susu atau Kijing Taiwan yang harus dikonsumsi manusia dalam sehari?

Jawaban :

Susu sapi

$$
\begin{aligned}
& B j=\frac{\text { Kgij }}{\text { Gij }} \times \frac{100}{B D D} \times 100 \\
& =\frac{1000 \mathrm{mg}}{143 \mathrm{mg}} \times \frac{100}{100} \times 100 \\
& =699,3007 \mathrm{gr}
\end{aligned}
$$

Kijing Taiwan

$$
\begin{aligned}
& B j=\frac{K g i j}{G i j} \times \frac{100}{B D D} \times 100 \\
& =\frac{1000 m g}{366} \times \frac{100}{100} \times 100 \\
& =273,2240 \mathrm{gr}
\end{aligned}
$$

Berdasarkan hasil perhitungan didapatkan fakta bahwa untuk memenuhi kalsium harian tubuh perlu mengkonsumsi susu sapi sebanyak 700 gr atau mengkonsumsi Kijing Taiwan sebanyak 273 gr.

URT (Ukuran Rumah Tangga) dari konsumsi susu adalah satu gelas berukuran 200 gr. Maka untuk memenuhi kebutuhan kalsium harian tubuh perlu mengkonsumsi kurang lebih 3,5 gelas susu per hari. Sementara untuk Kijing Taiwan URT nya adalah satu sdm berukuran 15 gr. Berarti untuk memenuhi kebutuhan kalsium harian tubuh perlu mengkonsumsi kurang lebih 18 sdm kerang.

\section{Analisis Perbandingan Biaya}

Berikut merupakan perbandingan pengalokasian dana untuk pemenuhan kalsium bagi keluarga dengan sumber susu dan kerang.

Susu merk X dengan netto 200 gram memiliki harga $\mathrm{Rp} 20.000,00$. Setiap satu gelas susu dianjurkan 4 sendok susu bubuk ( \pm 35 gram). Diasumsikan keluarga yang mengkonsumsi susu tersebut berjumlah 4 orang (ayah, ibu, dan dua orang anak), maka dalam satu hari akan dihabiskan susu sebanyak $=4 \times 35 \times$ $3.5=490$ gram. Hal ini berarti dalam satu hari sebuah keluarga harus menganggarkan dana sebesar $=\frac{490}{200} \times$ $R p 20000=R p 49.000,00$

Kijing Taiwan dijual di pasaran dengan harga sekitar Rp 14.000,00 per kg. Diasumsikan keluarga yang mengkonsumsi Kijing Taiwan tersebut berjumlah 4 orang (ayah, ibu, dan dua orang anak), maka dalam satu hari akan dihabiskan Kijing Taiwan sebanyak $4 \times 273=1.092$ gram $=$ $1.092 \mathrm{~g}$. Hal ini berarti dalam satu hari sebuah keluarga harus menganggarkan dana sebesar $=1,092 \times$ Rp. 14.000,- $=$ Rp. $15.288,-$.

Dari hasil perhitungan analisis biaya di atas dapat diketahui bahwa untuk memenuhi kebutuhan kalsium keluarga dalam satu hari harus dianggarkan dana sebesar $\mathrm{Rp}$ 49.000,- untuk susu dan Rp 15.288,- untuk kerang. 


\section{Sosialisasi Kijing Taiwan sebagai Sumber Kalsium \\ Dalam menyosialisasikan Kijing} Taiwan sebagai sumber kalsium, ada kerjasama antara pejabat kelurahan seperti ibu kepala desa dengan mahasiswa yang mengetahui informasi mengenai Kijing Taiwan sebagai sumber kalsium. Hal ini dikarenakan target penyuluhan ini yaitu para ibu rumah tangga sehingga penerimaan informasi tersebut lebih tersampaikan. Ibu rumah tangga dipilih sebagai obyek penyuluhan karena mereka memiliki peranan penting dalam penyusunan menu makanan untuk keluarganya. Penyuluhan ini diberikan pada saat ada kegiatan dimana para ibu rumah tangga berkumpul, seperti acara arisan RT atau RW ataupun acara PKK.

Dari kegiatan penyuluhan ini diharapkan para ibu rumah tangga yang mengikutinya mampu mengaplikasikan ilmu yang telah didapat demi terpenuhinya asupan kalsium setiap anggota keluarga. Selain itu, diharapkan dari lingkup yang kecil ini dapat mengurangi kasus osteoporosis di Indonesia.

\section{KESIMPULAN DAN SARAN Kesimpulan}

Tujuan dari pembuatan penelitian ini telah tercapai. Dalam penelitian ini kita dapat mengetahui kandungan kalsium pada Kijing Taiwan serta mengetahui berapa gram Kijing Taiwan yang harus dikonsumsi untuk memenuhi asupan kalsium per hari per orangnya. Selain itu juga dapat melakukan sosialisasi Kijing Taiwan sebagai sumber kalsium masyarakat yaitu dengan memberikan penyuluhan langsung kepada para ibu rumah tangga dengan bekerja sama dengan pejabat kelurahan. mengkonsumsi Kijing Taiwan sebagai asupan kalsiumnya, dan perlu adanya sosialisasi pada masyarakat luas bahwa Kijing Taiwan dapat memberikan alternatif dalam memberikan asupan kalsium. Sosialisasi yang dilakukan dapat berjalan secara kontinu melalui berbagai tema dalam penyajian Kijing Taiwan bagi anggota keluarga seperti menu masakan untuk keluarga atau menu bekal makanan yang berbahan dasar kerang.

\section{DAFTAR PUSTAKA}

AOAC, 1995. Official Methods of Analysis of The Association of Analytical Chemist, Washington D.C.

Dept. Gizi Masy.FEMA IPB. 2009. Daftar Komposisi Bahan Makanan.

Deearyana. 2006. Kalsium. http://biasbiru. blogspot.com $/ 2006 / 08 / \mathrm{kalsium}$ calcium.html. [3 Maret 2009]

Departemen Kesehatan Repubik Indonesia. 2009. Konsumsi Kalsium untuk Cegah Osteoporosis. http://www.DepkesRI.co.id [3 Maret 2009]

Departemen Kesehatan Republik Indonesia. 2007. Terapi Patah Tulang karena Osteoporosis. http://www.DepkesRI. co.id [3 Maret 2009]

Direktorat Jenderal Perikanan. 1995. Kerang. http://Pusat informasi pelabuhan perikanan.html. [2 Maret 2009]

Koral AUP/STP Papua. 2008. Kerang: Kecil Bentuknya, Besar Kandungan Kalsiumnya. http://www.loligopapua. wordpress.com/2008/01/10/kerangkecil-bentuknya-besar-kandungankalsiumnya/ [30 Maret 2009]

Nasoetion, Amini, Evy Damayanthi.2009. Ilmu Gizi Dasar. Dept Gizi Masy.FEMA : IPB

\section{Saran}

Dengan adanya penelitian ini diharapkan masyarakat dapat beralih untuk 
Fitofarmaka, Vol. 2 No.1, Juni 2012 : 27-35

Rahayu, SYS. 2011. Biomineralisasi pada Proses Pelapisan Inti Mutiara Kijing Air Tawar Anodonta woodiana (Unionidae). Disertasi. IPB, Bogor. 